\title{
Duygusal Kıskançlık Ölçeği Üniversite Öğrencileri Formu: Geçerlik ve Güvenirlik Çalışmaları
}

\section{University Students Form of Emotional Jealousy Scale: Validity and Reliability Studies}

\author{
Seval KIZILDAĞ*
}

\begin{abstract}
Öz
Bu çalışmanın amacı, Duygusal Kıskançlık Ölçeği Üniversite Öğrencileri Formu'nun geçerlik ve güvenirlik çalışmalarını yapmaktır. Duygusal Kıskançlık Ölçeği Üniversite Öğrencileri Formu üç faktör (değersizlik hissi; ilişkisel doyumsuzluk ve aşkın yitimi ve beraber zaman geçirmede isteksizlik) ve 17 maddeden oluşmaktadır. Araştırmanın iki çalışma grubu bulunmaktadır. Birinci çalışma grubunu 158'si kadın (\%37) ve 92'si erkek (\%37) toplam 250 üniversite öğrencisi; ikinci çalışma grubunu da test tekrar test güvenirlik analizleri için çalışmaya dahil edilen 18'si kadın (\%54.5) ve 15'i erkek (\%45.5) toplam 33 üniversite öğrencisi oluşturmaktadır. Güvenirlik analizleri kapsamında Cronbach alfa güvenirlik katsayısı, madde toplam korelasyonları ve test-tekrar test güvenirliği incelenmiştir. Ölçeğin Cronbach alfa değeri .94; test-tekrar test korelasyon katsayıs1 .97 bulunmuştur. Ölçek madde toplam korelasyon değerlerinin .43 ile .79 arasinda değiştiği gözlenmektedir. Geçerlik analizi kapsamında, yapı geçerliği ve yordama geçerliğine bakılmıştır. Doğrulayıcı faktör analizleri sonucunda üç faktörlü model incelendiğinde $\chi^{2}=334.29, \chi^{2} / \mathrm{df}=2.88$; RMSEA $=.09$, $\mathrm{NFI}=.88, \mathrm{CFI}=.92, \mathrm{IFI}=.92$, $\mathrm{TLI}=.91$ ve $\mathrm{RFI}=.86$ değerleri elde edilmiştir. $\mathrm{Bu}$ değerler modelin veri uygunluğunun yeterli olduğunu göstermektedir. Özetle, ölçeğin üniversite öğrencileri üzerinde yapılan geçerlik ve güvenirlik çalışmaları sonuçları, bu ölçeğin üniversite öğrencilerinin kıskançlık düzeyini ölçebilecek niteliklere sahip olduğunu göstermektedir.
\end{abstract}

Anahtar Kelimeler: romantik kıskançlık, duygusal kıskançlık ölçeği, üniversite öğrencileri

\begin{abstract}
The aim of this study is to conduct the validity and the reliability studies for University Student Form of Emotional Jealousy Scale. University Student Form of Emotional Jealousy Scale is a scale that consists of 17 items and three factors as "feeling of valueless, relational dissatisfaction and loss of love, unwillingness for having time together". There are two study groups in this research. First study group consists of 158 female students (63\%) and 92 male students (37\%) and second study group consists of 18 female students (54.5\%) and 15 male students (45.5\%) for test-retest reliability analysis. Cronbach alpha reliability coefficient, totalitem correlation values, and test-retest reliability were examined on the scope of reliability analysis. Cronbach alpha value of the scale was found as .94; and test-retest correlation coefficient was found as .97. It is observed that total-item correlation values of the scale change between .43 and .79 . Confirmatory factor analysis, predictive validity, and findings directed to reliability studies concerning construct validity of the scale were presented. Model fit indices were found as $\chi^{2}=334.29, \chi^{2} / \mathrm{df}=2.88$; RMSEA $=.09, \mathrm{NFI}=.88, \mathrm{CFI}=.92, \mathrm{IFI}=.92$, TLI=.91, and RFI $=.86$ in the wake of analysis. These values show that model-data fit is sufficient. To sum up, it is concluded with the analysis that the university form of the scale is a valid and reliable measurement tool.
\end{abstract}

Keywords: romantic jealousy, emotional jealousy scale, university students

\section{GíRiş}

Romantik kıskançlık, bireyin kendilik değerine veya ilişkisine yönelik tehditler içeren karmaşık duygu, düşünce ve davranışlar bütünü olarak tanımlanmaktadır (White, 1981). Pines (1992a) ise romantik kıskançlığı, değer verilen bir ilişkiye veya onun niteliğine yönelik tehdit algısıyla oluşan karmaşık bir tepki olarak tanımlamakta ve romantik kıskançlığın içsel ve dışsal olmak üzere iki

* Arş. Gör. Dr., Adıyaman Üniversitesi, Eğitim Fakültesi, Adıyaman-Türkiye, e-posta: sevalpdr@gmail.com 
boyuttan oluştuğunu ifade etmektedir. Romantik kıskançlığın içsel boyutunda, belli duygular, bilişler ve fiziksel semptomların; dışsal boyutunda ise daha kolay bir şekilde dış dünyadan fark edilebilir davranışların yer aldığını belirtmektedir. Romantik kıskançlık tanımlarında ortak olan durum, sevilen birinin kaybedilme korkusuna ilişkin diğer kişinin yaşadığı karmaşık duygu, düşünce ve davranışları içermesidir. Bir başka ifadeyle, romantik kıskançlık çok boyutlu ve kapsamlı bir psikolojik yapıdır.

Literatürde cinsel kıskançlık ve duygusal kıskançlık olarak da sınıflandırılabilen romantik kıskançlığın her iki türünde de ortak olan davranışlar; çiftlerden birinin ilişki için daha az çaba harcaması ve partneri (eşi/sevgilisi) için çekici ve arzu edilebilir olmasındaki isteksizlik halinde birleşmektedir (Shackelford ve Buss, 1997). Buna karşın, çiftlerden birinde ilişki dışındaki üçüncü kişiyle daha fazla iletişim kurma, zaman geçirmeye isteklilik görülebilir. Üçüncü kişiye yönelik bu eğilim ile belirli bir başlatıcı olay arasındaki etkileşim romantik kıskançlığın bir sonucudur fakat kıskançlığı ortaya çıkarıcı bir olay yaşanmadığı sürece bu duygunun yaşanma olasılığı da düşebilir (Pines,1992b). Başlatıcı olay bazen partnerin bir başka kişiye ilgisinden dolayı kendi eşinden uzaklaşması ve ayrılması korkusuyla da tetiklenmektedir (Sharpsteen ve Kirkpatrick, 1997). Buradan hareketle, cinsel veya duygusal kıskançlık durumlarında temelde sevilen kişiyi bir şekilde kaybetme korkusunun öne çıktı̆̆ söylenebilir.

Romantik kıskançlığın boyutlarından biri olan cinsel kıskançlık, bireyin eşinin bir başkasıyla cinsel beraberlik yaşadığını bilmesi ya da bundan şüphelenmesi sonucunda yaşanan kıskançlıktır (Demirtaş-Madran, 2008). Shackelford ve Buss (1997) cinsel kıskançlığın en belirgin özelliklerini bazen cinsel isteksizlik veya uzaklaşma bazen abartılı bir şekilde cinsel konularla ilgilenme veya konuşma gibi tutarsız davranışlarla ilişkilendirmektedir. Aynı zamanda, cinsel davranışlarda normalden farklı davranma (sıklık veya yaşanma şekli gibi) cinsel kıskançlığın belirleyicileri olabilmektedir. Görüleceği üzere, romantik ilişkideki bir davranışın normal seyrinin dışında yaşanması ve çiftlerden birinin bu durumu tehdit olarak algılaması ve nihayetinde de romantik kıskançlı̆̆ yaşamasına neden olabilir.

Romantik kıskançlığın bir diğer boyutu olan ve bu çalışmanın temel alt yapısını oluşturan duygusal kıskançlı̆̆ doyumsuzluk ve aşkın yitimi; duygusal ihmal; beraber zaman geçirmede isteksizlik; pasif reddetme ve düşüncesizce davranışlar sergilemeye başlama; öfkeli, eleştiriye dayalı ve sorgulayıcı iletişime girme; belirli bir birey hakkında konuşmaktan kaçınma ve suçlu ve kaygılı bir iletişim tarzı benimseme olarak sıralanmıştır. Bu davranışların temelindeki duyguların düzenlenmesi veya kontrol edilmesi, romantik ilişkinin olumlu sürekliliği açısından önemli görülmektedir. Duyguların düzenlenmesinde yaşanan zorluklar duygusal tepkiyi kabul etmeme, amaç yönelimli davranışları sürdürmekte ve dürtü kontrolünde zorlanma, duygu düzenleme stratejilerini sinırlı kullanma, duygusal farkındalıktan yoksunluk ile ilişkilendirilmektedir (Gratz ve Roemer, 2004). Buradan hareketle, duygusal kıskançlığın da olumsuz duygular yaşama veya onları kontrol edememe gibi olası sorunlar doğuracağı söylenebilir.

İlgili literatürde, romantik kıskançlık ilişkilerde genellikle olumsuz duygularla eşleştirilmektedir. Pfeiffer ve Wong (1989) duygusal kıskançlığı korku, öfke, güvensizlik, üzüntü gibi hislerle ilişkilendirirken; Wreen (1989) kıskançlığı güvensizlik, kaybetme korkusu ve duygusal soğukluk ile ilişkilendirmektedir. Romantik ilişkide korku, öfke, güvensizlik veya duygusal soğukluk gibi duyguların ilişkinin niteliğini de olumsuz etkileyebileceği söylenebilir. Sağliklı bir ilişki güvensizlik, korku, ilgisizlik, değersizlik gibi durumların aksine; güven, ilgili olma, değerli hissetme gibi duygu durumlarını içermektedir. Bu sebeple, ilişkide sağlıklı bağlanma gerçekleştirmiş bireylerin romantik kıskançlıklarının da daha düşük düzeylerde olması beklenir.

Sharpsteen ve Kirkpatrick (1997) bağlanma ile romantik kıskançlık arasındaki ortak özellikleri ilişkiyi devam ettiren bir süreç olması; sevilen birinden gerçek veya olası ayrılmanın başlatılması; öfke, korku, üzüntü gibi duyguları içermesi ve kendiliğin ve ilişkilerin zihinsel modeli tarafindan düzenlenmesi açılarından ortaya koymuşlardır. Buunk (1997) yüksek düzeyde kıskançlığın kaygılı bağlanan bireylerde, daha sonra kaçınan bireylerde gözlendiğini belirtirken; güvenli bağlanan bireylerde kıskançlığın daha düşük düzeyde olduğunu belirtmektedir. Bununla birlikte, romantik kıskançlığın kaygılı bağlanmayla ilişkili olduğu (Knobloch, Solomon ve Cruz, 2001) ve güvenli 
bağlanma stiline sahip kişilerin duygusal aldatmayı cinsel aldatmadan daha stresli buldukları, kayıtsız bağlanma stiline sahip kişilerde ise cinsel aldatmayı daha büyük bir sorun olarak algıladıkları ifade edilmektedir (Levy ve Kelly, 2006). Görülebileceği üzere, ilişkilerde güven duygusu romantik kıskançlığın da yaşanma olasılığını ve biçimini etkileyebilmektedir.

Selterman ve Maier (2013) de güvenli bağlanan bireylerin güvensiz bağlanan bireylerden daha çok kıskançlık duygusunu deneyimlediklerini ve güvensiz bağlanmanın ilişkide tehdit yaratan yanlış algılamalarla ilişkilendirildiğini belirtmektedir. Simpson (1990) da güvensiz bağlanmada partnerin davranışına yönelik olumsuz davranış ve ihanet beklentilerinin arttığını ifade etmektedir. Aynı zamanda güvensiz bağlanan kişiler olumlu duygularını açıkça ifade edemezlerken; kızgınlık, öfke ve benzeri olumsuz duygularını ise düşmanca bir şekilde ifade edebilirler. Dolayısıyla güvensiz bağlanan kişilerde kıskançlık duygusunun ilişkiye daha zarar veren biçimde saldırganlık, şiddet gibi davranışa dönüşme olasılığ 1 daha yüksektir. Bununla birlikte, güvensiz bağlanan bireylerin olumlu deneyimlerden daha az bahsettikleri ve bu olumlu deneyimlerin etkilerinden yeterince yararlanmadıkları da bilinmektedir (Gentzler, Kerns ve Keener, 2010). Bir başka ifadeyle, güvensiz bağlanan bireyler yaşamlarını daha çok olumsuz yaşantılar üzerinden anlamlandırmaktadırlar.

Edalati ve Redzuan (2010) sevginin azalması, reddetme, güvensizlik, kendine güvenin kaybedilmesi, duygusal destek ve değerli olma duygusunun azalması ve korku temelli romantik kıskançlık ile saldırganlık arasında güçlü bir ilişkinin olduğunu belirtmektedir. Örneğin, romantik ilişkisi olan üniversite öğrencilerinde bağlanma ve romantik kıskançlık ilişkisinin incelendiği Karakurt (2001) tarafından yapılan bir araştırmada, korkulu bağlanan bireylerin güvenli bağlananlardan daha yüksek düzeyde davranışsal kıskançlık gösterdikleri; saplantılı bağlananların da güvenli bağlananlardan daha yüksek düzeyde olumsuz ve yetersizlik duygusu taşıdıkları bulunmuştur. Aynı zamanda, söz konusu bu çalışmada romantik kıskançlıkla baş etmede, güvenli bağlanan bireylerin ilişkiyi korumaya daha yatkın oldukları; kayıtsız bağlananların ise daha düşük düzeyde ilişkiyi korumaya yönelik oldukları; saplantılı bağlanma özelliği gösterenlerin ise en yüksek düzeyde içselleştirme gösteren grup oldukları gözlenmiştir.

Literatürde romantik kıskançlık kavramı ilişkide her zaman sağlıksız bir duruma işaret etmeyebilir. Örneğin, Attridge (2013) aşk ile simgeleştirilen tepkisel kıskançlığın ilişki için olumlu bir özelliğe sahip olduğunu ifade etmektedir. Şöyle ki, birbirine aşık olan bir çift kıskançlık tepkisi ile ilişkilerine verdikleri değeri ortaya koyabilirler ve bu sayede ilişkilerini daha canlı tutmaları mümkün olabilir. Aynı zamanda, romantik kıskançlığın yaşanmasında veya davranışa dönüşmesinde bireysel, toplumsal ya da kültürel faktörler etkili olabilmektedir. Örneğin, Türkiye'de kıskançlık romantik ilişki içerisinde kabul edilebilir normal bir duygu olarak ele alınmaktadır. Aynı zamanda, "seven insan kıskanır" sözü ile bu duygunun normalleştirildiği söylenebilir ancak ilişkide kıskançlık her zaman sağlıklı bir şekilde yaşanmayabilir ya da davranışa dönüşmeyebilir. Sağlıklı bir şekilde çözülemeyen kıskançlık, ilişkinin olumlu seyrini olumsuza çevirebilir. Şiddetten eş cinayetine kadar farklı şekillerde sonuçlar doğuran romantik kıskançlığın (Pines ve Friedman, 1998) boşanma nedenlerinden biri (Pines, 1992b) olması büyük bir olasılıktır.

Özetle, romantik kıskançlık ilişkilerde daha çok olumsuz yönleri ile ele alınmaktadır. İlişkide sevginin azalması gibi bir süreçten ilişkinin sonlandırılması gibi sonuçlar doğurabilen romantik kıskançlığın sağlıklı bir şekilde ele alınması için üzerinde çalışılması gerekmektedir. Bununla birlikte, Erikson'un gelişim dönemlerinden biri olarak tanımladığı "yakınlığa karşı yalıtılmışlık dönemine" denk gelen üniversite yıllarındaki bireylerin ilişkilerini etkileyebilecek duygusal kıskançlık gibi bir psikolojik yapının araştırılması ayrıca önemlidir. Yakınlığa karşı yalıtılmış sürecinde olan bir birey eğer ilişki içerisinde kendi varlığını koruyarak sevebiliyor ve başkasıyla doyum verici bir paylaşımda bulunabiliyorsa yakınlık duygusunu geliştirebilir buna karşın sevebilme, ilişki kurma veya sürdürme gibi durumları bazı gerekçelerle gerçekleştiremiyorsa yalıtılmışlık yaşayabilir. Birey romantik ilişki içinde olsun ya da olmasın bu duruma ilişkin bir önyargı veya olumsuz düşünce geliş̧irmişse olası romantik ilişkisini de sağlılı olmayan ilişkiler üzerine kurabilir.

Duygusal kıskançlığın ilişkiye zarar veren olumsuz özelliği dikkate alındığında, bu duygunun romantik ilişki başlamadan önce fark edilmesi ve ilişkiye zarar vermeyen bir düzeye getirilmesi için 
üzerinde çalışılması gereklidir. Bununla birlikte, görece flört şiddetinin arttığı, ilişkilerin daha hızlı şekilde kopabildiği günümüz koşullarında ilişkiye zarar verebilecek nitelikteki olumsuz içerikli ilişki kavramlarından biri olan romantik kıskançlığın ilişkisi olmayan bireylerde ölçülmesi ilişkinin seyri için önemli bir ipucu olabilir. Bir başka deyişle, romantik ilişkisi olmayan üniversite öğrencilerinin ilerde kuracakları romantik bir ilişkide duygusal kıskançlık düzeylerini tespit edebilmek ilişkinin niteliğine yönelik önleyici çalışmaların da temelini oluşturabilir. Özellikle evlilik öncesi psikolojik danışma hizmetleri sunulurken, bu hizmeti sunan merkez veya birimlerde duygusal kıskançlığın ölçülmesi bu konuda yapılan araştırmaların kuramsal ve uygulama alt yapısını da güçlendirebilir.

\section{Araştırmanın Amacı}

Bu çalışmanın amacı, Duygusal Kıskançlık Ölçeği Üniversite Öğrencileri Formu'nun geçerlik ve güvenirlik çalışmalarını yapmaktır. Böylece bu araştırmada "Duygusal Kıskançlık Ölçeği Üniversite Ögrencileri Formu geçerli ve güvenilir bir ölçme aracıdır.” hipotezi test edilmektedir.

\section{YÖNTEM}

$\mathrm{Bu}$ araştırma, Duygusal Kıskançlık Ölçeği Üniversite Öğrencileri Formu'nun romantik ilişkisi olmayan üniversite öğrencileri için geçerlik ve güvenirlik çalışmalarının yapıldığı betimsel bir araştırmadır. Betimsel bir araştırmanın, bazı olgu, olay veya durumları açıklamaya çalışan bir araştırma (Boyacı ve Baykuş, 2015) olma özelliğinden hareketle, bu araştırmada üniversite öğrencileri üzerinde duygusal kıskançlık kavramının psikometrik özellikleri açılanmaya çalışılmıştır.

\section{Çalışma Grubu}

$\mathrm{Bu}$ araştırmanın çalışma grubunu, 2015-2016 Eğitim-Öğretim Yılı Güz Döneminde Adıyaman Üniversitesi'nde öğrenimlerine devam etmekte olan ve rasgele örnekleme yöntemiyle seçilen toplam 283 dördüncü sınıf öğrencisi oluşturmaktadır.

Birinci çalışma grubu: Bu çalışma grubu, 158'si kadın (\%63) ve 92'si erkek (\%37) toplam 250 üniversite öğrencisinden oluşmaktadır. Bu öğrencilerin yaş ortalaması 22.41'dir. Bu öğrencilerin 64'ü (\%25.6) İslami İlimler Fakültesi’ne, 65’i (\%26) Fen-Edebiyat Fakültesi’ne ve 121’i (\% 48.4) de Eğitim Fakültesi'ne devam etmektedirler.

İkinci çalışma grubu: Bu çalışma grubu ise test tekrar test analizleri için çalışmaya dahil edilen 18'si kadın $(\% 54,5)$ ve 15 'i erkek $(\% 45.5)$ toplam 33 üniversite öğrencisiden oluşmaktadır. Bu öğrencilerin yaş ortalaması ise 22.9 'dur.

\section{Veri Toplama Araçları}

\section{Kişisel bilgi formu}

Araştırmacı tarafından geliştirilen Kişisel Bilgi Formu'nda katılımcıların yaş, cinsiyet, öğrenim gördükleri fakülteleri belirlemeye yönelik üç soruya yer verilmiştir.

Eş duygusal kıskançlık ölçeği (EDKÖ)

Evli bireylerin duygusal kıskançlık düzeylerini ölçmek amacıyla Kızıldağ ve Yıldırım (2017) tarafından geliştirilmiştir. Ölçek geliştirme sürecinde ilgili alan yazın incelendikten sonra, romantik ilişkisi olan 10 bireyle görüşme, 33 evli birey üzerinde pilot uygulama, 267 evli birey üzerinde açıklayıcı faktör analizi, 303 evli birey üzerinde ise doğrulayıcı faktör analizi yapılmıştır. Açıklayıcı faktör analizi sonucunda EDKÖ’nün üç faktörlü bir yapıda olduğu görülmüştür. Faktörlerdeki maddeler, içerikleri açısından incelenerek birinci faktöre "değersizlik hissi", ikinci faktöre "ilişkisel doyumsuzluk ve aşkın yitimi" ve üçüncü faktöre ise "beraber zaman geçirmede isteksizlik" isimleri 
verilmiştir. EDKÖ’nün doğrulayıcı faktör analizinde ölçekten iyi düzeyde uyum indeksleri elde edilmiştir. Ölçme modelinin genel uyum katsayıları $\chi^{2} 204=600.988 ; \mathrm{p}=0.00 ; \mathrm{x}^{2} / \mathrm{sd}=2.95 ; \mathrm{GFI}=$ .84 ; $\mathrm{AGFI}=.80$; NFI $=.87$; CFI $=.91$ ve RMSEA $=0.08$ 'dir. EDKÖ'nün güvenirliği iki ayrı veri seti üzerinde test edilmiştir: Birincisi, 267 kişiden elde edilen veri seti üzerinde, EDKÖ'nün Cronbach Alpha katsayıs1 .951 ve 303 kişiden elde edilen veri üzerinde ise Cronbach Alpha katsayıs1 947 bulunmuştur. İkincisi, iki yarı test güvenirliği incelenmiştir. EDKÖ maddeleri tek numaralı ve çift numaralı maddeler olarak ayrılmış ve aralarındaki korelasyon, 267 birey için .925, 303 birey için .922 olarak bulunmuştur. Elde edilen güvenirlik katsayıları EDKÖ’nün evli bireylerin duygusal kıskançlık düzeylerini ölçmek amacıyla güvenle kullanılabileceğini göstermektedir. Ölçek maddeleri "1=Hiç Kıskanmam; 2= Biraz Kıskanırım ve 3=Çok Kıskanırım" şeklinde puanlanmaktadır. Ölçekten alınan yüksek puanlar evli bireylerin ilişkilerindeki duygusal kıskançlık düzeylerinin yüksek olduğu anlamına gelmektedir. Ölçekten alınabilecek puan aralığı 22-66 arasında değişmektedir. Bununla birlikte ölçeğin boyutundaki maddeler istatistiksel olarak "tek puan" vermeye uygundur. İlk boyuttaki maddelerin evlilik ilişkisinde bir eşin diğer eşten hissettiği değersizlik hissi, önem verilmeme gibi olumsuz duyguları içeren maddelerden oluşmasından dolayı bu şekilde adlandırılmıştır. $\mathrm{Bu}$ boyuttaki maddelere örnek olarak "Karşı cinste birilerinin yaptıklarını hoşgörü ile karşılarken aynı durumda benim yaptıklarımı eleştirmesini" ve "Beni karşı cinsten birileriyle klyaslayarak benim beceriksiz, başarısız vb. olduğumu söylemesini" maddeleri verilebilir. İkinci alt boyuttaki maddelerin evlilik ilişkisinde bir eşin diğer eşin davranışlarından algıladığı ilgisizlik sebebiyle "ilişkisel doyumsuzluk ve aşkın yitimi" olarak adlandırılmıştır. Bu boyutta yer alan maddelere "Karşı cinsten birilerinin dikkatini çekecek davranışlarda bulunması" ve "Karşı cinsle ilişkilerine sınır koymamasını" maddeleri örnek olarak verilebilir. Üçüncü alt boyuttaki maddelerin de evlilik ilişkisinde beraber zaman geçirmedeki isteksizliği ifade ettiğinden "Beraber zaman geçirmede isteksizlik" olarak adlandırılmıştır. Bu boyutta yer alan maddelere "Benimle vakit geçirmek yerine başka işlerle uğraşmayı tercih etmesini" ve "Her firsatta arkadaşlarıyla buluşup görüşmesini” örnek verilebilir.

\section{Duygu düzenlemede zorluklar ölçeği (DDZÖ)}

Duygu düzenlemede yaşanan zorlukları değerlendirmek için Gratz ve Roemer (2004) tarafindan geliştirilen ölçeğin Türkçe geçerlik ve güvenirlik çalışması Rugancı ve Gençöz (2010) tarafından gerçekleştirilmiştir. Ölçek 5'li Likert tipinde ve 36 maddeden oluşmaktadır. Ayrıca ölçek netlik, farkındalık, kabul, dürtü, amaç, strateji olmak üzere altı alt boyut içermektedir. Ölçekten alınan yüksek puan ilgili alt boyutlarda daha fazla zorluk yaşandığı anlamına gelmektedir. DDZÖ’nin tüm ölçek iç-tutarlık değerinin .93 alt boyutlar için ise .80 ile . 89 arasında olduğu belirtilmektedir (Gratz ve Roemer, 2004). Türkçe geçerlik ve güvenirlik çalışmasında da orijinal faktör yapısının elde edildiği ve altı alt boyutun kullanılabileceği belirtilmektedir. Ayrıca geçerlik ve güvenirlik sonuçlarına göre ölçeğin hem genelinin hem de alt boyutlarının geçerli ve güvenir düzeyde olduğu belirtilmektedir.

\section{İlişki ölçekleri anketi (ï.Ö.A.)}

Yetişkin bireylerde dört bağlanma prototipini (güvenli, kayıtsız, korkulu ve saplantılı) ölçmeyi amaçlayan İlişki Ölçekleri Anketi Griffin ve Bartholomew (1994) tarafindan geliştirmiş ve Sümer ve Güngör (1999) tarafindan Türkçe uyarlaması yapılmıştır. Ölçek 7'li Likert tipinde olup 17 maddeden oluşmaktadır. Ölçeğin orijinal formunun alt ölçeklerinin Cronbach alfa değerleri .70 civarındadır. IÖA'nın orijinalinde alt ölçeklerinin Cronbach alfa iç tutarlılık katsayıları 0.41 ile 0.70 arasında bulunmuştur. Ölçeğin Türkçeye uyarlama çalışmasında ise, iç tutarlık katsayılarının 0.27 ile 0.61 ; test tekrarı sonuçlarının .54 ile .78 arasında değerler aldığı bildirilmiştir.

\section{İşlem}

Araştırmanın uygulamaları doğrudan araştırmacı tarafından yapılmıştır. Uygulamalar, öğrencilere araştırmanın amacı açıklanarak ve gönüllü katılımları sağlanarak gerçekleştirilmiştir. Öğrenciler ortalama 15 dakika içinde ölçek setini yanıtlamışlardır. 


\section{Verilerin Analizi}

Çalışma kapsamında elde edilen veriler, bilgisayar ortamına girildikten sonra gerekli veri ayıklama işlemleri yapılmıştır. Verilerin analizinde SPSS 21 ve AMOS 21 kullanılmıştır. Ölçek setinden eksik dolduran yedi katılımcının ölçekleri çıkarılmış ve analize geriye kalan öğrencilerin verisi dahil edilmiştir.

\section{BULGULAR}

\section{Yapı geçerliği}

Ölçeğin yapı geçerliğine ilişkin doğrulayıcı faktör analizi, yordama geçerliği çalışmalarına yönelik bulgular aşağıda sırasıyla sunulmuştur:

Öncelikle ölçeğin faktörleri arasındaki ilişkilere bakılmış ve bu ilişkilere yönelik korelasyon değerleri Tablo 1'de gösterilmiştir.

Tablo 1. Ölçek Faktörleri Arasındaki Korelasyon Değerleri

\begin{tabular}{llll}
\hline Faktörler & 1 & 2 & 3 \\
\hline 1. & Değersizlik Hissi & 1 & \\
2. & İlişkisel Doyumsuzluk ve Așkın Yitimi & $.84^{* *}$ & 1 \\
3. & Beraber Zaman Geçirmede İsteksizlik & $.51^{* *}$ & $.53^{* *}$ \\
\hline$* * p<0.01$ & &
\end{tabular}

Tablo 1 incelendiğinde, ölçek faktörleri arasındaki korelasyon değerlerinin .51 ile .84 arasında değiştiği gözlenmektedir $(p<0.01)$. Korelasyon katsayısının mutlak değer olarak, .70-1.00 arasında olmas1 yüksek; 0.70-.30 arasında olması orta ve .30- .00 arasında olması da düşük düzeyde bir ilişkiyi göstermektedir (Büyüköztürk, 2010). Buradan hareketle, bu çalışmadaki ölçek faktörleri arasındaki korelasyon değerlerinin düşük-orta ve yüksek düzeyde ilişkiye sahip olduğu görülmektedir.

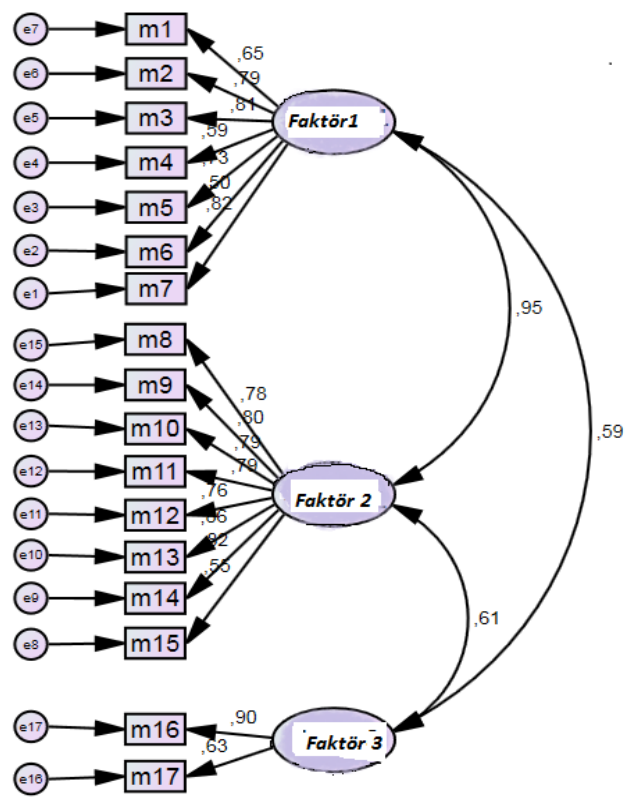

Şekil 1. Duygusal Kıskançlık Ölçeği Üniversite Öğrencileri Formu için Doğrulayıcı Faktör Analizi 
Şekil 1 incelendiğinde, ölçek faktörlerindeki maddeler arasındaki ilişkiler, değersizlik hissi faktöründe madde faktör yüklerinin $(\lambda) .65-.82$, ilişkisel doyumsuzluk ve aşkın yitimi faktöründe madde faktör yükleri $(\lambda) .55-.78$ aralığında, beraber zaman geçirmede isteksizlik faktöründe ise faktör yükleri $(\lambda) .63$ - .90 arasında değiştiği görülmektedir. Doğrulayıcı faktör analizi, daha önceden oluşturulan bir model aracılığıyla gözlenen değişkenlerden yola çıkarak gizil değişken (faktör) oluşturmaya yönelik bir işlemdir (Çokluk, Şekercioğlu ve Büyüköztürk, 2010). Schumacker ve Lomax (2004) doğrulayıcı faktör analizinin en önemli özelliğinin tasarlanan modelin veriye uygun olup olmadığını belirlemek olduğunu ifade eder. Buradan hareketle, üç faktörlü orijinal ölçek yapısının, üniversite öğrencilerinden elde edilen veriye uygun olup olmadığını test edebilmek için sadece doğrulayıcı faktör analizi kullanılmıştır. Bu bilgiye ek olarak, üniversite öğrencileri üzerinde uyarlaması yapılan ölçeğin araştırmacılar tarafından geliştirilen formu üzerinde açıklayıcı faktör analizi yapıldığı için ölçek üzerinde sadece doğrulayıcı faktör analizi yapıldığı söylenebilir. Dolayısıyla, doğrulayıcı faktör analizleri sonucunda üç faktörlü model incelendiğinde $\chi^{2}=334.29$, $\chi^{2} / \mathrm{df}=2.88 ; \mathrm{RMSEA}=.09, \mathrm{NFI}=.88, \mathrm{CFI}=.92, \mathrm{IFI}=.92, \mathrm{TLI}=.91$ ve $\mathrm{RFI}=.86$ değerleri elde edilmiştir. RMSEA değerinin 0.08 ile 0.10 arasında yer alması orta düzey bir uyuma işaret ederken (MacCallum, Browne ve Sugawara, 1996) ve Kline (2010) $\chi^{2} / \mathrm{df} \leq 3$ düzeyinde olmasını kabul edilebilir olarak ifade etmektedir. Aynı zamanda, .00-1.00 arasında değer alan IFI (Artırmalı uyum indeksi), CFI (Karşılaştırmalı uyum indeksi), TLI (Tucker-Lewis indeksi) ve RFI (Göreceli uyum indeksi) değerlerinin 1'e yakın değer alması daha iyi bir uyuma işaret etmektedir (Bentler ve Bonett, 1980). Buradan hareketle, uyum indekslerin iyi bir uyuma işaret ettiği söylenebilir.

\section{Yordama Geçerliği}

Duygusal Kıskançlık Ölçeği Üniversite Öğrencileri Formu "değersizlik, ilişkisel doyumsuzluk ve aşkın yitimi ve zaman geçirmede isteksizlik" faktörleri ile Duygu Düzenlemede Zorluklar Ölçeği ve İlişki Ölç̧ekleri Anketi faktörleri ile olan korelasyon değerleri Tablo 2'de verilmiştir.

Tablo 2. DKÖ Üniversite Öğrencileri Formu Faktörlerinin DDZÖ ve İÖA Faktörleri Arasındaki Korelasyon Değerleri

\begin{tabular}{|c|c|c|c|c|c|c|c|c|c|c|c|c|c|}
\hline & 1 & 2 & 3 & 4 & 5 & 6 & 7 & 8 & 9 & 10 & 11 & 12 & 13 \\
\hline 1 & 1 & & & & & & & & & & & & \\
\hline 2 &, $85 * *$ & 1 & & & & & & & & & & & \\
\hline 3 &, $51^{* *}$ &, $55^{* *}$ & 1 & & & & & & & & & & \\
\hline 4 & 12 & 11 &,- 01 & 1 & & & & & & & & & \\
\hline 5 & ,03 &,- 01 & ,06 &, $35 * *$ & 1 & & & & & & & & \\
\hline 6 &,$- 17 * *$ &,- 09 &,$- 14 *$ & ,17* & ,05 & 1 & & & & & & & \\
\hline 7 &,$- 20 * *$ &,- 06 &,- 11 &,- 09 &,$- 16^{*}$ &, $47 * *$ & 1 & & & & & & \\
\hline 8 &,- 08 &,- 01 & ,02 & ,04 &, $22 * *$ &, $44^{* *}$ &, $33^{* *}$ & 1 & & & & & \\
\hline 9 &,$- 21 * *$ &,- 09 &,- 08 & ,05 & 11 &, $58 * *$ &, $57 * *$ & ,48** & 1 & & & & \\
\hline 10 & 11 & 13 &,- 05 & ,15* & ,07 &,- 10 &,$- 25 * *$ &,- 08 &,$- 17 * *$ & 1 & & & \\
\hline 11 & 11 & 11 &,- 05 & ,06 & ,07 & ,06 & 07 & 12 & ,14* &, $25 * *$ & 1 & & \\
\hline 12 &,- 02 &,- 02 & ,04 &,- 03 & ,04 & ,09 & ,06 & ,08 & 10 &,- 03 & ,07 & 1 & \\
\hline 13 &,- 05 &,- 02 & ,02 &,$- 14^{*}$ &,- 07 & $18^{* *}$ & $25^{* *}$ &, $21 * *$ &, $22 * *$ &,$- 31 * *$ &, $28 * *$ & ,01 & 1 \\
\hline
\end{tabular}

$\left[{ }^{* *} p=0.001 ;{ }^{*} p=0.05 ; 1\right.$ : edko_değersizlik;2: edko_doyumsuzluk; 3: edko_isteksizlik; 4:ddzö_netlik; 5: ddzö_farkındalık; 6. Ddzö_dürtü; 7:ddzö_kabul; 8: ddzö_amaç; 9: ddzo_strateji; 10: ybbö_güvenli; 11: ybbö_korkulu; 12: ybbö_saplantıll; 13: ybbo_kayitsiz]

Tablo 2 incelendiğinde Duygusal Kıskançlık Ölçeği Üniversite Öğrencileri Formu faktörleri ile DDZÖ ve İÖA ölçek puanları arasındaki korelasyon değerleri incelendiğinde korelasyon değerlerinin -.31 ile ile .85 arasında değiştiği gözlenmektedir. Korelasyon katsayısının mutlak değer olarak, .70-1.00 arasında olması yüksek; 0.70-.30 arasında olması orta ve .30 -0.00 arasında olmas1 da düşük düzeyde bir ilişkiyi göstermektedir (Büyüköztürk, 2010). Buradan hareketle, bu çalışmada ölçek faktörleri arasındaki korelasyon değerlerinin düşük, orta ve yüksek düzeyde ilişkiye sahip olduğu görülmektedir. 


\section{Güvenirlik Analizi}

Ölçeğin faktörlerine ilişkin yapılan güvenirlik analizleri sonucunda Cronbach alfa değerlerinin .45 ile .91 arasında değiştiği gözlenmektedir. Aynı zamanda iki hafta arayla toplam 33 üniversite öğrencisinden oluşan ikinci çalışma grubu üzerinde yapılan test tekrar test korelasyon katsayısı .97 $(\mathrm{p}<0.05)$ bulunmuştur. Ölçeğin bütününe ait Cronbach alfa değeri ise .94 bulunmuştur. Güvenirlik katsayının .90 üstünde olması "mükemmel", .80 civarındaki değerlerin "çok iyi" ve .70 civarındaki değerlerin ise yeterli olduğu belirtilmektedir (Kline, 2010). Bu değerler, ölçek faktörlerinin yeterli güvenirliğe sahip olduğunu göstermektedir.

Tablo 3. Duygusal Kıskançlık Ölçeği Üniversite Öğrencileri Formu Madde Toplam Korelasyonları

\begin{tabular}{lcc}
\hline Faktörler & Maddeler & Düzeltilmiş Madde Toplam Korelasyonları (rjx ) \\
\hline Değersizlik Hissi & $\mathrm{m} 1$ & .63 \\
& $\mathrm{~m} 2$ & .72 \\
& $\mathrm{~m} 3$ & .75 \\
& $\mathrm{~m} 4$ & .61 \\
& $\mathrm{~m} 5$ & .68 \\
& $\mathrm{~m} 6$ & .52 \\
& $\mathrm{~m} 7$ & .78 \\
\hline İlişkisel Doyumsuzluk ve Aşkın Yitimi & $\mathrm{m} 8$ & .74 \\
& $\mathrm{~m} 9$ & .74 \\
& $\mathrm{~m} 10$ & .73 \\
& $\mathrm{~m} 11$ & .75 \\
& $\mathrm{~m} 12$ & .73 \\
& $\mathrm{~m} 13$ & .79 \\
& $\mathrm{~m} 4$ & .77 \\
& $\mathrm{~m} 15$ & .59 \\
\hline Beraber Zaman Geçirmede İsteksizlik & $\mathrm{m} 16$ & .59 \\
& $\mathrm{~m} 17$ & .43 \\
\hline
\end{tabular}

Tablo 3 incelendiğinde ölçeğin madde toplam korelasyonlarının .43 ile .79 arasında değiştiği gözlenmektedir. Korelasyon katsayısının mutlak değer olarak, .70-1.00 arasında olması yüksek; 0.70-.30 arasında olması orta ve .30-0.00 arasında olması da düşük düzeyde bir ilişkiyi göstermektedir (Büyüköztürk, 2010). Buradan hareketle, madde toplam korelasyon değerlerinin orta ve yüksek düzeyde ilişkiye sahip olduğu görülmektedir.

\section{SONUÇLAR VE TARTIŞMA}

Duygusal Kıskançlık Ölçeği Üniversite Formu'nun geçerlik ve güvenirlik çalışmalarının yapıldığı bu araştırmada, analizler sonucunda ölçeğin geçerli ve güvenilir bir ölçme aracı olduğu sonucuna ulaşılmıştır. Duygusal Kıskançlığı Ölçeği Üniversite Formu 17 madde ve "değersizlik hissi, ilişkisel doyumsuzluk ve aşkın yitimi ve beraber zaman geçirmede isteksizlik" olmak üzere üç faktörden oluşan bir ölçektir. Değersizlik hissi boyutunda 1, 2, 3, 4, 5, 6 ve 7 numaralı maddeler; ilişkisel doyumsuzluk ve aşkın yitimi boyutunda $8,9,10,11,12,13,14$ ve 15 numaralı maddeler ve beraber zaman geçirmede isteksizlik boyutunda ise 16 ve 17 numaralı maddeler yer almaktadır. Faktörlerde yer alan madde sayıları incelendiğinde, üçüncü faktörde sadece iki maddenin olduğu görülmektedir. Raubenheimer (2004) istisna durumlar dışında faktörlerde en az üç maddenin o faktörü daha iyi açıklayabileceğini ifade etmektedir. Bu çalışmada ise 16. ve 17. maddelerin madde toplam korelasyonların kabul edilebilir düzeyde ve maddelerin doğrudan duygusal kıskançlığın literatürdeki kuramsal alt yapısı ile ilişkili olması faktördeki madde sayısının sınırlı fakat bahsedilen nedenlerden ötürü kabul edilebilir olduğunu açıklayabilir. Faktörlerde yer alan madde örneklerine bakıldığında, değersizlik hissi boyutunda "Karşı cinsten birilerinin başarılarını takdir ederken benim başarılarımı küçümsemesini" ve "Hatalar karşısında başkalarını affederken, aynı durumda beni affetmemesini" maddeleri yer almaktadır. İlişkisel doyumsuzluk ve aşkın yitimi olarak isimlendirilen ikinci boyutta "Karşı cinsten birilerinin dikkatini çekecek davranışlarda bulunması" ve "Karşı cinsle ilişkilerine 
sınır koymamasını" gibi maddeler bulunurken; beraber zaman geçirmede isteksizlik olarak adlandırılan üçüncü faktörde ise "Benimle vakit geçirmek yerine başka işlerle uğraşmayı tercih etmesini” ve "Her firsatta arkadaşlarıyla buluşup görüşmesini" maddeleri bulunmaktadır. Buradan hareketle, ölçek maddeleri ve faktörleri literatürde duygusal kıskançlığın kuramsal yapısına (Shackelford ve Buss, 1997) uygun olduğundan bu ölçeğin gerek romantik ilişkisi olan gerekse de romantik ilişkisi olmayan bireylerdeki duygusal kıskançlığın belirlenmesinde işlevsel bir ölçme aracı olduğu düşünülmektedir. Bir başka ifadeyle, duygusal kıskançlık kavramının bireylerde genellikle gözlenebilir bir durum olduğu ve romantik ilişkisi olan veya olmayan bireylerde de var olabilen bir duygu olduğu söylenebilir.

Bununla birlikte, Duygusal Kıskançlığı Ölçeği Üniversite Formu'ndan alınan yüksek puan duygusal kıskançlık düzeyinin yüksekliğine işaret etmektedir. Ölçekten alınabilecek puan aralığı 17-51 arasında değişmektedir. Üçlü Likert tipinde olan ölçekte maddeler "1=Hiç Kıskanmam; 2= Biraz Kıskanırım ve 3=Çok Kıskanırım" şeklinde puanlanmaktadır. Ölçek maddeleri arasında reverse (tersten puanlanan) madde olmadığından sadece düz puanlama yapılmaktadır. Ölçeğin geçerlik analizleri kapsamında yapı geçerliği ve yordama geçerliğine bakılmıştır. Doğrulayıcı faktör analizleri sonucunda ölçeğin orijinalindeki üç faktörlü yapısı doğrulanmıştır. Buradan hareketle, ölçeğin gerek evli bireyler üzerinde geliştirilmiş hali gerekse de romantik ilişkisi olmayan üniversite öğrencileri üzerindeki yapılan hali ile duygusal kıskançlık ile ilgili benzer yapıları ortaya koyduğu söylenebilir. Aynı zamanda analiz sonucunda model uyum indeksleri; $\chi^{2}=334.29, \chi^{2} / \mathrm{df}=2.88$; RMSEA $=.09, \mathrm{NFI}=.88, \mathrm{CFI}=.92, \mathrm{IFI}=.92, \mathrm{TLI}=.91$ ve $\mathrm{RFI}=.86$ bulunmuştur. $\mathrm{RMSEA}$ değerinin 0.08 ile 0.10 arasında yer alması orta düzey bir uyuma işaret ederken (MacCallum, Browne ve Sugawara, 1996) ve Kline (2010) $\chi^{2} / \mathrm{df} \leq 3$ düzeyinde olmasını kabul edilebilir olarak ifade etmektedir. Aynı zamanda, .00-1.00 arasında değer alan IFI (Artırmalı uyum indeksi), CFI (Karşıllaştırmalı uyum indeksi), TLI (Tucker-Lewis indeksi) ve RFI (Göreceli uyum indeksi) değerlerinin 1'e yakın değer alması daha iyi bir uyuma işaret etmektedir (Bentler ve Bonett, 1980). Yordama geçerliği kapsamında, Duygusal Kıskançlık Ölçeği Üniversite Formu'nun “değersizlik, ilişkisel doyumsuzluk ve aşkın yitimi ve beraber zaman geçirmede isteksizlik" faktörleri ile Duygu Düzenlemede Zorluklar Ölçeği ve İlişki Ölçekleri Anketi faktörleri arasındaki korelasyon değerleri incelenmiştir. Yapılan korelasyon analizi sonucunda, değerlerin -.31 ile ile .85 arasında değiştiği gözlenmiştir. Bununla birlikte, güvenirlik analizleri kapsamında Cronbach alfa güvenirlik katsayısına, madde toplam korelasyonlarına bakılmış ve test-tekrar test güvenirliği incelenmiştir. Ölçeğin Cronbach alfa değeri .94; test-tekrar test korelasyon katsayıs1 .97 bulunmuştur. Güvenirlik katsayısının, $0.00 \leq \alpha \leq 0.40$ ise ölçek maddeleri güvenilir değil; $0.40 \leq \alpha \leq 0.60$ ise ölçeğin güvenirliği düşük; $0.60 \leq \alpha \leq 0.80$ olmas1 ise ölçek oldukça güvenilir ve $0.80 \leq \alpha \leq 1.00$ ise ölçek yüksek düzeyde güvenilir bir ölçek (Kalayc1, 2010) olduğunu göstermesi bu çalışma kapsamında ele alınan Duygusal Kıskançlık Ölçeği Üniversite Formu'nun da iyi bir psikometrik bir özelliğe sahip olduğunu göstermektedir. Aynı zamanda, ölçek madde toplam korelasyon değerlerinin .43 ile .79 arasında değiştiği gözlenmektedir. Korelasyon katsayısının mutlak değer olarak, .70-1.00 arasında olması yüksek; 0.70-.30 arasında olması orta ve .30-0.00 arasında olması da düşük düzeyde bir ilişkiyi göstermektedir (Büyüköztürk, 2010).

\section{ÖNERILER}

Duygusal Kıskançlık Ölçeği Üniversite Formu'nun geçerlik ve güvenirliğine ilişkin elde edilen kanıtlar, ölçeğin romantik ilişkisi olmayan üniversite öğrencilerinin duygusal kıskançlık düzeylerini geçerli ve güvenilir olarak ölçecek nitelikte olduğunu göstermektedir. Buradan hareketle, romantik ilişkiler üzerinde çalışan araştırmacı ve uygulamacılar, Duygusal Kıskançlık Ölçeği Üniversite Formu'nu üniversite öğrencileri üzerinde yapacakları çalışmalarda güvenle kullanılabilirler. Bu sayede romantik ilişkisi olmayan üniversite öğrencilerinin gelecekte kuracakları romantik ilişkilerine zarar verme olasılığı olan duygusal kıskançlık durumlarını önceden tespit etmeleri mümkün olabileceğinden önleyici çalışmalar için de temel oluşturabilir. Aynı zamanda, Evlilik Öncesi Psikolojik Danışma alanında çalışan psikolojik danışmanlar özellikle deneysel çalışmalarda duygusal kıskançlık durumunun zararlı etkilerini azaltmaya yönelik çalışmaları da mümkün olabilir. Ayrıca, 
ilerde yapılacak betimsel çalışmalarda duygusal kıskançlık, bağlanma ve duygu düzenlemede zorluklar arasındaki ilişkiler incelenebileceği gibi kültürel bağlamda duygusal kıskançlığın ilişkilerin niteliğine etkileri de araştırılabilir.

\section{KAYNAKÇA}

Attridge, M. (2013). Jealouys and relationship closeness: Exploring the good (reactive) and ban (suspicious) sides of romantic jealousy. Sage Open, 3(1), 1-16.

Bentler, P. M., \& Bonett, D. G. (1980). Significance tests and goodness of fit in the analysis of covariance structures. Psychological Bulletin, 88, 588-606.

Boyacı, A. ve Bozkuş, K. (2015). Araştırma yöntemleri desen ve analiz (Çev. A. Aypay). Ankara: Anı Yayıncilik.

Buunk, B. (1997). Personality, birth order, and attachment styles as related to various types of jealousy. Personality and Individual Differences, 23(6), 997-1006.

Büyüköztürk, Ş. (2010). Sosyal bilimler için veri analizi el kitabı. Ankara: Pegem Akademi.

Çokluk, Ö., Şekercioğlu, G. ve Büyüköztürk, Ş. (2010). Sosyal bilimler için çok değiş̧kenli istatistik. Ankara: Pegem Akademi.

Demirtaş-Madran, A. (2008). Duygusal ve cinsel kıskançlık açısından temel cinsiyet farklılıkları: Evrimsel yaklaşım ve süregelen tartışmalar. Türk Psikiyatri Dergisi, 19(3), 300-309.

Edalati, A., \& Redzuan, M. (2010). The relationship between jealousy and agression: A review of literatures related to wives’ aggression. European Journal of Scientific Research, 39(4), 498-504.

Gentzler, A. L., Kerns, K. A., \& Keener, E. (2010). Emotional reactions and regulatory responses to negative and positive events: Associations with attachment and gender. Motivation and Emotion, 34(1), 78-92.

Gratz, K. L., Roemer, L. (2004). Multidimensional assessment of emotion regulation and dysregulation. Journal of Psychopathology \& Behavioral Assessment, 26, 41-54.

Griffin, D. W., \& Bartholomew, K. (1994). Models of the self and other: Fundamental dimensions underlying measures of adult attachment. Journal of Personality and Social Psychology, 67(3), 430-445.

Karakurt, G. (2001). Yetişkin bağlanma stillerinin romantik kıskançlık üzerindeki etkileri (Yüksek lisans tezi, Orta Doğu Teknik Üniversitesi, Psikoloji Anabilim Dalı, Ankara). http://tez2.yok.gov.tr/ adresinden edinilmiştir.

Kızıldağ, S., Yıldırım, İ. (2017). Eş duygusal kıskançlık ölçeği'nin geliştirilmesi. Kuram ve Uygulamada Eğitim Bilimleri, 17(1), 175-190.

Kline, R. B. (2010). Principles and practice of structural equation modeling. New York: Guilford Press.

Knobloch, L. K., Solomon, D. H., \& Cruz, M. G. (2001). The role of relationship development and attachment in the experience of romantic jealousy. Personal Relationships, 8(2), 205-222.

Levy, K. N., \& Kelly, K. M. (2010). Sex differences in jealousy: A contribution from attachment theory. Psychological Science, 21(2), 168-173.

MacCallum, R. C., Browne, M. W., \& Sugawara, H. M. (1996). Power analysis and determination of sample size for covariance structure modeling. Psychological Methods, 1(2), 130-149.

Pfeiffer, S. M., \& Wong, P. T. P. (1987). Multidimensional jealousy. Journal of Social and Personal Relationships, 6, 181-196.

Pines, A. M. (1992a). Romantic jealousy: Five perspectives and an integrative approach. Psychotherapy, 29(4), 675-683.

Pines, A. M. (1992b). Romantic jealousy: Understanding and conquering the shadow of love. New York: St. Martin's.

Pines, A. M., \& Friedman, A. (1998). Gender differences in romantic jealousy. The Journal of Social Psychology, 138(1), 54-71.

Raubenheimer, J. (2004). An item selection procedure to maximise scale reliability and validity. Journal of Industrial Psychology, 30(4), 59-64.

Rugancı, R. N., \& Gençöz, T. (2010). Psychometric properties of the Turkish version of the difficulties in emotional regulation scale. Journal of Clinical Psychology, 66, 442 - 455.

Schumacker, R. E., \& Lomax, R. G. (2004). A Beginner's Guide to Structural Equation Modeling. New Jersey: Taylor \& Francis.

Selterman, D. F., \& Maier, M. A. (2013). Secure attachment and material reward both attenuate romantic jealousy. Motive Emotion, 37, 765-775.

Shackelford, T. K., \& Buss, D. M. (1997). Cues to infidelity. Peronality and Social Psychology Bulletin, 23, 1034-1045.

Sharpsteen, D. J., Kirkpatrick, L. A. (1997). Romantic jealousy and adult romantic attachment. Journal of Personality and Social Psychology, 72(3), 627-640. 
Simpson, J. A. (1990). Influence of attachment styles on romantic relationships. Journal of Personality and Social Psychology, 59(5), 971-980.

Sümer, N. ve Güngör, D. (1999). Yetişkin bağlanma stilleri ölçeklerinin Türk örneklemi üzerinde psikometrik değerlendirmesi ve kültürlerarası bir karşılaştırma. Türk Psikoloji Dergisi, 14(43), 71-106.

White, G. L. (1981). Some correlates of romantic jealousy. Journal of Personality, 49(2), 129-147.

Wreen, M. J. (1989). Jealousy. Nous, 23(5), 635-652.

\section{EXTENDED ABSTRACT}

\section{Introduction}

Romantic jealousy is defined as a whole of complex emotions, thoughts, and behaviors, which include threats against individual's self-worth or relationship (White, 1981). The common behavior that can be observed in both sexual and emotional jealousy, which are classified as two forms of romantic jealousy, is one of the spouse making less effort for the relationship and the reluctance for being attractive and desirable for the the spouse (Shackelford and Buss, 1997). Behaviors that unveil emotional jealousy are sorted by Shackelford and Buss (1997) as relational dissatisfaction and loss of love; emotional neglect; reluctance for spending time together; passive rejection and starting to behave inconsiderately; communicating in an angry, critical, and interrogative way; avoiding from talking about a specific person; and adopting a guilty and nervous communication style. In the literature, romantic jealousy in relationships may generally be associated with negative emotions. While Pfeiffer and Wong (1989) explain emotional jealousy with some feelings like fear, anger, lack of confidence, sadness; Wreen (1989) states that jealousy grounds on lack of confidence, fear of losing, and emotional alienation. Under current circumstances with increasing divorce rates and faster relationship breakdowns, it is a preventive action to evaluate jealousy, which is one of the relationship concepts with a negative content that may damage the relationship, also in individuals, who are not involved in a romantic relationship. In other words, to be able to determine the emotional jealousy level of the university students, who are not currently involved in a romantic relationship, in their future romantic relationships can underlie preventive studies regarding the quality of relationship. From this point of view, the aim of this study is to make validity and reliability studies of Spouse Emotional Jealousy Scale (Kızıldağ and Yıldırım, 2017), which was developed on married individuals, on university students, who are not involved in a romantic relationship. Thereby, this study seeks an answer to the question of "Is the University Form of Emotional Jealousy Scale a valid and reliable measurement tool?

\section{Method}

University Student Form of Emotional Jealousy Scale is a descriptive research, within which validity and reliability studies for university students, who are not involved in a romantic relationship, are conducted. There are two study groups in this research. The first study group consisted of a total of 250 university students with 158 students were female (63\%) and 92 students were male (37\%) and the second study group consisted of a total of 33 university students with 18 students were female (54.5\%) and 15 students were male (45.5\%), who were included in the study for test-retest reliability analyses. In the study, Personal Information Form consists of three questions to determine the age, gender, and faculty of the participants was used. Spousal Emotional Jealousy Scale that was developed by Kızıldağ and Yıldırım (2017) with the aim of measuring emotional jealousy level of married couples was used for validity and reliability studies. For predictive validity, Difficulties in Emotion Regulation Scale, which was developed by Gratz and Roemer (2004) and of which Turkish validity and reliability studies were conducted by Rugancı and Gençöz (2010), was used. Developed by Griffin and Bartholomew (1994) and adopted to Turkish by Sümer and Güngör (1999) Relation Scales Questionnaire, which aims to measure four attachment prototypes (secure, dismissive avoidant, fearful, preoccupied) in adults, was also used. For data analysis, SPSS 21 and AMOS 21 programs were used. 


\section{Results and Discussion}

In the scope of validity analysis, construct validity and predictive validity were examined. Cronbach alpha reliability coefficient, total-item correlation, and test-retest reliability were examined in the scope of reliability analysis. Model fit indices were found as $\chi^{2}=334.29, \chi^{2} / \mathrm{df}=2.88$; RMSEA $=.09$, $\mathrm{NFI}=.88, \mathrm{CFI}=.92$, $\mathrm{IFI}=.92$, $\mathrm{TLI}=.91$, and $\mathrm{RFI}=.86$ as a result of confirmatory factor analysis. A RMSEA value between 0.08 to 0.10 indicates a medium level cohesion (MacCallum, Browne ve Sugawara, 1996). Kline (2010) also claimed that the model fit is acceptable, if $\chi^{2} / \mathrm{df} \leq 3$. As a result of the correlation analysis, it is observed that the values change between -.31 and .85. In addition to this, Cronbach alpha reliability coefficient, total-item correlation, and test-retest reliability were examined in the scope of reliability analysis. As a result of the reliability analysis, which was carried out concerning the factors of the scale, it is observed that Cronbach alpha values change between .45 and .91. Test-retest correlation coefficient is .97 $(p<0.05)$.

Cronbach alpha value that belongs to the whole scale was found as .94 . Meanwhile, it is observed that the item-total correlation values of Emotional Jealousy Scale University Form change between .43 and .79. The evidence on the validity and reliability of Emotional Jealousy Scale University Form shows that the scale is capable of measuring the emotional jealousy status of the university students, who are not involved in a romantic relationship, in a valid and reliable way. Emotional Jealousy Scale University Form is a scale that consists of 17 items and three factors that are "feeling of worthlessness, relational dissatisfaction and loss of love and unwillingness for spending time together". A high score on the scale indicates a high level of jealousy. The scores range between 17 and 51. The ratings on this three-point Likert-type scale are " $1=$ I am never jealous; $2=I$ am a little jealous; 3=I am very jealous". Since there are no reverse items among the scale items, straight grading is made. To sum up, it can also provide a basis for preventive studies, as it is possible to identify the jealousy statuses of the university students that might damage their future romantic relationships, through the scale that can measure the emotional jealousy levels of the university students, who are not involved in a romantic relationship, in a valid and reliable way. At the same time, this scale can be used by the counselors that are working in the Premarital Counseling, to determine the jealousy statuses especially in experimental studies and thus studies can be conducted to decrease the harmful effects of jealousy. 